\title{
Comparison of Outcomes between Elective Tracheostomy versus Emergency Tracheostomy
}

\author{
TARIQUE KHAN ${ }^{1}$, ABID RASHID ${ }^{2}$, MUHAMMAD AWAIS SAMEE ${ }^{3}$, AHMED ALI $^{4}$ \\ ${ }^{1}$ Senior Registrar Department of ENT, University College of Medicine \& Dentistry/University of Lahore Teaching Hospital Lahore \\ ${ }^{2}$ Consultant, Department of Otorhinolargyngology, Alhada Armed Froces Hospital Taif KSA \\ ${ }^{3}$ Assistant Professor, Department of ENT Unit-II, Services Hospital, Lahore \\ ${ }^{4}$ Senior Registrar, Department of ENT, Khairpur Medical College Khairpur Mirs \\ Correspondence to Dr. Tarique Khan, E-mail: tariqabbasi4072@gmail.com Cell: 0300-3040089
}

\begin{abstract}
Aim: To compare the frequency of early postoperative complications of elective tracheostomy and emergency tracheostomy.

Study design: Comparative/observational study

Place and duration of study: Department of ENT/Head \& Neck Surgery, Mayo Hospital Lahore from $1^{\text {st }}$ July 2012 to $31^{\text {st }}$ December 2012.

Methodology: One hundred patients of both genders undergoing tracheostomy were enrolled. All the patients were divided equally in two groups; Group A (elective) comprised 50 patients and group B (emergency) tracheostomies also comprised 50 patients. Early postoperative complications were examined and compare between both groups.

Results: There were $28(56 \%)$ and $22(44 \%)$ males and females in group A with mean age $42.45 \pm 10.55$ years while in group B $30(60 \%)$ and $20(40 \%)$ patients were male and females with mean age $43.06 \pm 9.84$ years. Patients received emergency tracheostomy had high rate of postoperative complications as compared to elective tracheostomy (36\% vs $16 \%)$. The difference was statistically significant $(P<0.05)$.

Conclusion: Early postoperative complications were high in patients underwent emergency tracheostomy as compared to elective tracheostomy.

Keywords: Early complications, Elective tracheostomy, Emergency tracheostomy
\end{abstract}

\section{INTRODUCTION}

Tracheostomy is a procedure where a stoma is formed between the skin and the anterior trachea wall. It was first identified some 3500 years ago and is therefore one of the first operations to be documented. Alexander the Great was said to have performed a tracheostomy in the fourth century BC. ${ }^{1}$ The procedural indications are increasing day by day. Initially, tracheostomy was performed to relieve the high airway obstruction. Its indication became increasingly comprehensive, now being used more and more as a temporary procedure for access to airways, particularly for anesthetic and artificial ventilation purposes. Similarly, long-term or permanent tracheostomy as well as extreme respiratory distress is being shown to increase sleep apnoea syndrome and terminal malignant neoplasm. . $^{2,3}$

Tracheostomy has its advantages not without associated risk and complications. The increased use of tracheostoma in recent decades has led to an increase in complications in parallel. Furthermore, little focus is placed on postoperative management of medical and nursing instruction to avoid complications. The treatment of the patient after trecheostomy involves a large + of highly skilled staff, elaborate machining and a lot of time and resources. Problems include related feeding issues, communication and educational growth in paediatric patients. ${ }^{4}$

Elective tracheostomy is far more advantageous than waiting for an emergency. Morbidity and mortality caused by the procedure are not exclusivity of the procedure per

Received on 09-02-2021

Accepted on 13-06-2021 se, but most often due to patient age, general patient condition, whether the tracheostomy is the primary procedure or part of some other procedure, procedural urgency, surgeon's capacity, timing of the procedure, traylike instrument, tracheostomy tuval quality, postoperative $\mathrm{c}$ c This procedure is more difficult for pediatric patients and is associated with a higher degree of morbidity and mortality than in adults. The younger the child undergoes the operation, the greater the possibility of complications. ${ }^{7,8}$

The present study was conducted with the goal to compare the early post operative complications of elective tracheostomy with emergency tracheostomy.

\section{MATERIALS AND METHODS}

This comparative/observational study was conducted at Department of ENT/Head \& Neck Surgery, Mayo Hospital Lahore from $1^{\text {st }}$ July 2012 to $31^{\text {st }}$ December 2012 after approval from Ethical Committee. A total of 100 patients of both genders undergoing tracheostomy were enrolled. All the patients were divided equally in to two groups. Group A (elective) comprised 50 patients and group B with same number of patients received emergency tracheostomy. Patients with INR $>1.6$ or platelet counts $<50.000 / \mu \mathrm{L}$ or patients who had not stopped taking aspirin (or related medications) five days before tracheostomy, outside of the operation theater (e.g. in bedside) tracheostomies, and percutaneous procedure or cricothyroidotomy were also excluded from this analysis. Tracheostomy was conducted on traditional open surgical techniques in the operation theater. The local anesthesia and correct positioning of the patient, transverse skin incision in elective cases and vertical skin incision for emergencies, underlying structural 
dissection and the trachea cancelation with a sufficient size tube were involved. Postoperatively, the ENT ward or intensive care unit held patients. During the first seven days of the post-operatory procedure, complications were reported and labeled as "yes" or "no" when present or absent. Pneumothorax presence was evaluated by auscultation and confirmed by chest $x$-ray. In the history of aspiration, the presence of tracheoesophagous fistula was clear. The data was entered and analyzed through 24. Pearson chi-square has been tested to compare the complications between the two classes and $\mathrm{P}<0.05$ considered significant.

\section{RESULTS}

There were $28(56 \%)$ and $22(44 \%)$ males and females in group A with mean age $42.45 \pm 10.55$ years while in group $\mathrm{B}, 30(60 \%)$ and $20(40 \%)$ patients were male and females with mean age $43.06 \pm 9.84$ years. Mean $B M l$ in group $A$ was $25.38 \pm 2.24 \mathrm{~kg} / \mathrm{m}^{2}$ and in group $B$, it was $25.22 \pm 2.44$ $\mathrm{kg} / \mathrm{m}^{2}$ (Table 1). Patients received emergency tracheostomy had high rate of postoperative complications as compared to elective tracheostomy (36\% Vs 16\%). The difference was statistically significant with $\mathrm{P}$-value was $<0.05$ (Table 2)

Table 1: Demographic information of all the patients

\begin{tabular}{|c|c|c|c|}
\hline Variables & Group A & Group B & P-value \\
\hline Mean age (yrs) & $42.45 \pm 10.55$ & $43.06 \pm 9.84$ & $>0.05$ \\
\hline Mean BMI $\left(\mathrm{Kg} / \mathrm{m}^{2}\right)$ & $25.38 \pm 2.24$ & $25.22 \pm 2.44$ & $>0.05$ \\
\hline \multicolumn{4}{|l|}{ Gender } \\
\hline Male & $28(56 \%)$ & $30(60 \%)$ & \multirow{2}{*}{$>0.05$} \\
\hline Females & $22(44 \%)$ & $20(40 \%)$ & \\
\hline
\end{tabular}

Table 2: Comparison of frequency of early postoperative complications between both groups

\begin{tabular}{|l|c|c|c|}
\hline Complication & Group A & Group B & P-value \\
\hline Yes & $8(16 \%)$ & $18(36 \%)$ & \multirow{2}{*}{0.001} \\
\hline No & $42(84 \%)$ & $32(64 \%)$ & \\
\hline
\end{tabular}

\section{DISCUSSION}

Tracheostomy is one of the most successful operations worldwide with a high incidence of complications associated with elective or emergency tracheostomy..$^{9,10}$ There were $58 \%$ male while $42 \%$ patients were females. Majority of patients $70 \%$ were ages 35 to 60 years. These results were similar to many of previous studies in which male patients were high in numbers $60 \%$ to $80 \%$ with average age of 40 years. ${ }^{11,12}$

In present study, we found that patients received emergency tracheostomy had high rate of postoperative complications as compared to elective tracheostomy (36\% vs $16 \%$ ). The difference was statistically significant $(P<0.05)$. Previous studies have found that the rate of complications is higher with emergency tracheostomy as compared with elective tracheostomy. ${ }^{13-17}$ This pattern of increased rate of complications with emergency tracheostomy has been observed in immediate complications as well as early and late complications. ${ }^{18}$ Moreover, postoperative bleeding (hemorrhage) has been found to be among the most common early postoperative complication as reported by Francois et $\mathrm{al}^{19}$.
Kumar et $\mathrm{al}^{20}$ were found to be more frequent in emergency tracheostomies. Kumar et $\mathrm{al}^{20}$ also reported commoner complications were mucous deposition (6.86\%), blockage of tracheostomy canula (6.29\%), bleeding from multiple attempts (6.06\%), excessive bleeding (2.94\%).

A prospective study with a much larger patient sample would be needed, of course, to conclude whether indeed these individual early postoperative complications do occur more frequently in emergency tracheostomies with statistical significance. Nevertheless, when all early postoperative complications are taken as a whole, even the present study with a combined sample size of 100 patients is able to show that these complications occur significantly more frequently with emergency tracheostomies.

\section{CONCLUSION}

Early postoperative complications have been concluded to be large in patients with emergency tracheostomy rather than elective tracheostomy. Hemorrhage is the most common early postoperative complication. This can be attributed to the surgeon's less than optimal working circumstances in an emergent situation where both surgeon and patient are nervous and panicked.

Conflict of interest: None

\section{REFERENCES}

1. Asherson N. Tracheostomy: Sudden death from delayed air embolism. J Laryngol Otol 1958; 72: 743-5.

2. Bent JP, Smith RJ. Aerocele after tracheocutaneous fistula closure. Int J Pediatr Otorhinolaryngol 1998; 42(3): 257-61.

3. Blot F, Similowski T, Trouillet JL, Chardon, P, Korach JM, Costa MA, et al. Early tracheotomy versus prolonged endotracheal intubation in unselected severely ill ICU patients. Intensive Care Med 2008; 34: 1779-87.

4. Pracy P. Scott-Brown's Otolaryngology, Head Neck Surg. $7^{\text {th }}$ ed. Hodder Arnold; 2008.

5. Crysdale WS, Feldman RI, Naito K. Tracheostomies: a 10year experience in 319 children. Ann Otol Rhinol Laryngol 1998; 97:439-43.

6. Hamid AA, Sattar F, Shaheen, Khan NS, Zakirullah. Complications of tracheostomy. J Postgrad Med Inst 2009;18:385-90.

7. Adetinuola EJ, Bola AY, Olanrewaju MI, Oyedotun AA, Timothy OO, Alani AS, et al. Tracheostomy in south western Nigeria: any change in pattern? J Med Med Sci 2011;2(7):997-1002.

8. Suslu N, Ermutlu G, Akyol U. Pediatric tracheostomy: comparison of indications and complications between children and adults. Turkish J Ped 2012;54:497-501.

9. Mitchell RB, Hussey HM, Setzen G, Jacobs IN, Nussenbaum $B$, Dawson $\mathrm{C}$, et al. Clinical consensus statement: tracheostomy care. Otolaryngol Head Neck Surg 2013;148(1):6-20.

10. Morris LL, Whitmer A, Mclntosh E. Tracheostomy care and complications in the intensive care unit. Crit Care Nurse 2013; 33(5):18-30.

11. Muhammad R, Khan F, Rehman F, Iqbal J, Khan M, Ullah G. Early complications of elective and emergency tracheostomy. J Ayub Med Coll Abbottabad 2012;24(1):44-7.

12. Sreelakshmi K. A comparative study on elective and emergency tracheostomies in a Tertiary Hospital of Andhra Pradesh. Int J Sci Stud 2018;6(8):184-92.

13. Rashid $H$, Taous A. Comparative study on complications of emergency and elective tracheostomy. Bangladesh $J$ Otorhinolaryngol 2015; 21: 69-75. 
14. Shafique S, Shaikh AA, Punjabi SK. Complications of tracheostomy at a tertiary care hospital. Pak Oral Dent $\mathrm{J}$ 2014; 34: 609-12.

15. Anehosur VS, Karadiguddi P, Joshi VL, Lakkundi BC, Ghosh $A$, Krishnan G. Elective tracheostomy in head and neck surgery: our experience. J Clin Diagn Res 2017; 11: ZC36-9.

16. Khammas A, Dawood M, Hamad A. (2017) Evaluation of early complications of open surgical tracheostomy. Mustansiriya Med J 2017; 16(2): 36-42.

17. Pal P, Sood AS, Singla S. Early complications of tracheostomy: a study on 100 patients at a single tertiary care centre. Int J Otorhinolaryngol Head Neck Surg 2018;4:21721.
18. Watanabe $\mathrm{Y}$, Umehara $\mathrm{T}$, Harada $\mathrm{A}$, Aoki M, Tokunaga $\mathrm{T}$, Suzuki S, et al. Successful closure of a tracheocutaneous fistula after tracheostomy using two skin flaps: a case report. Surg Case Rep 2015;1(1):1-3.

19. Kawale MA, Keche PN, Gawarle SH, Bhat SV, Buche A. A prospective study of complications of tracheostomy and management in tertiary care hospital in rural area. Int $\mathrm{J}$ Otorhinolaryngol Head Neck Surg 2017;3:687-92.

20. Kumar VAK, Kiran NAS, Kumar VA, Ghosh A, Pal R, Reddy $\mathrm{VV}$, et al. The outcome analysis and complication rates of tracheostomy tube insertion in critically ill neurosurgical patients: a data mining study. Bull Emerg Trauma 2019;7(4):355-60. 